\title{
The Effect of Hydroxybenzoate Lithium Complexes in Inducing Apoptosis in HT-1080 Human Fibrosarcoma Cells
}

\author{
Jassem G. Mahdi, ${ }^{1}$ Eamon J. Mahdi, ${ }^{2}$ Amal Al-Hazzaa, ${ }^{3}$ and Chris J. Pepper ${ }^{4}$ \\ ${ }^{1}$ College of Medicine, Shaqra University, Riyadh 11691, Saudi Arabia \\ ${ }^{2}$ School of Medicine, Cochrane Medical Education Centre, Heath Park, Cardiff CF14 4YU, UK \\ ${ }^{3}$ Zoology Department, King Saud University, Riyadh 11495, Saudi Arabia \\ ${ }^{4}$ Institute of Cancer and Genetics, School of Medicine, Cardiff University, Cardiff CF14 4XN, UK
}

Correspondence should be addressed to Jassem G. Mahdi; jmahdi@su.edu.sa

Received 26 March 2013; Revised 7 July 2013; Accepted 19 July 2013

Academic Editor: Shoji Natsugoe

Copyright (C) 2013 Jassem G. Mahdi et al. This is an open access article distributed under the Creative Commons Attribution License, which permits unrestricted use, distribution, and reproduction in any medium, provided the original work is properly cited.

There has been a growing interest in the beneficial effects of simple phenolic acids and their ability to exhibit various biological activities. The aim of this study was to assess in vitro biological activities of 2-, 3-, and 4-hydroxybenzoate lithium (HBLi) complexes on HT-1080 human fibrosarcoma cells by methods of using a metabolic activity assay, immunochemical and morphological techniques. Results showed that HBLi complexes exert their cytotoxic activities in a concentration- and chemical structuredependent manner in the following order: 4-HBLi > 3-HBLi > 2-HBLi. Flow cytometry displayed evidence of apoptosis induced by 3 -HBLi (21.8\%) and 4-HBLi (33.2\%). These results were verified by SEM, which revealed the formation of apoptotic bodies. In addition, these 3-HBLi and 4-HBLi caused an increase in HT-1080 cell cycle arrest in G0/G1 phase when compared to the controls ( $25 \%$ and $30.6 \%$, resp.) when cells were treated with $6 \mathrm{mM}$ for 24 hours. Immunochemical studies related to the molecular mechanism of apoptosis indicated that HBLi complexes downregulated the expression of Bcl-2 and upregulated Bax, p53, and caspases-3 in a concentration-dependent manner. HBLi complexes lowered Bcl-2/Bax ratios and induced the expression of p53 and caspase-3. These results suggest that HBLi complexes may exert their apoptotic effects through mitochondrial-mediated, caspasedependent, apoptotic mechanisms.

\section{Introduction}

Hydroxybenzoic acids (HBA) are a group of molecules that belong to simple phenolic acids, a major class of plant secondary metabolites widely distributed in plants. The parent molecule in this group is benzoic acid, encompassing three substituted hydroxyl groups analogous at ortho-, meta-, and para-positions, or $\mathrm{C} 1, \mathrm{C} 2$, and $\mathrm{C} 3$, respectively. These compounds exert various biological activities, including antioxidant, anticancer, and antimicrobial properties [1-3]. In addition, they exhibit different physicochemical properties and interactions with the primary metabolites and display various biological properties [4-6]. HBAs readily interact with metal ions to form hydroxybenzoate (HB) complexes, which are more biologically effective than HBAs or the free metal ions. Zinc salicylate, for example, was found to be more potent than salicylic acid and acetylsalicylic acid in terms of its ability to inhibit cell proliferation and induce apoptosis in cancer cells $[7,8]$. Metal complexes, particularly transition element metals, interact with DNA noncovalently producing changes in the structure of the DNA, thereby interfering with replication and transcription processes $[9,10]$. Interest in the therapeutic use of medicinal inorganic chemistry has led to the development of different anticancer agents, including cisplatin, carboplatin, and bis(thiosemicarbazone) [11, 12].

It has long been appreciated that transition organometallic complexes modulate molecular apoptotic pathways of cancer cells. Similarly, monovalent $\left(\mathrm{Na}^{+}\right)$and divalent $\left(\mathrm{Ca}^{2+}\right)$ 2-HB complexes were also found to exhibit these biological effects but at concentrations between 2 and $20 \mathrm{mM}[6,13,14]$. Generally, each organometallic complex has its own chemi$\mathrm{cal} /$ biochemical mode of interaction, particularly in terms of 
<smiles>O=C(O)c1ccccc1O</smiles>

ortho- or 2 -HBLi<smiles>O=C(O)c1ccccc1O</smiles>

ortho- or $2-\mathrm{HBLi}$<smiles>[14CH3]OC(=O)c1ccc(O)cc1</smiles>

para- or 4-HBLi

FIGURE 1: The chemical structure of HBLi complexes.

interactions with DNA. Therefore, HBLi complexes should be considered as distinct compounds and cannot be conflated with other complexes. Given the significant activity of 2-HB metal ion complexes, we examined the apoptotic effects of 2-, 3-, and 4-HBLi complexes on human HT-1080 fibrosarcoma cells. These HBLi complexes have the same molecular formula but different positions of the hydroxyl group (Figure 1).

\section{Materials and Methods}

2.1. Cell Culture. HT-1080 fibrosarcoma cell line (American Type Culture Collection; Rockville, MD,USA) was cultured at $37^{\circ} \mathrm{C}$ in a humidified atmosphere containing $5 \% \mathrm{CO}_{2}$. An optimal Dulbecco's Minimum Essential Medium (DMEM, Gibco, USA) was supplemented with $10 \%$ fetal bovine serum (FBS) and 1\% gentamicin-streptomycin (GIBCO BRL), 1\% L-glutamine, $0.1 \%$ hepes buffer $(1 \mathrm{M}), 0.1 \%$ sodium pyruvate (104 $1 \mathrm{M})$, and $0.1 \%$ ascorbic acid. HT-1080 cells were cultured for 3 days (based on the growth curve of HT-1080 cells), giving approximately $70 \%$ confluence and then further for another $24 \mathrm{~h}$ and $72 \mathrm{~h}$ with different concentrations of $\mathrm{HBLi}$ complexes.

2.2. Cell Metabolic Activity. HT-1080 cells were seeded at $5 \times 10^{4}$ cells per well in a 96-well plate for 3 days under optimal growth conditions. The medium was replaced with fresh medium with or without increasing concentrations of HBLi complexes $(0.1-8 \mathrm{mM})$ for up to $72 \mathrm{~h}$. Cell metabolic activity was measured using meta-(4,5-dimethylthiazol-parayl)-2,5-diphenyltetrazolium bromide (MTT) reagent. The assay detects the ability of the cells to reduce tetrazolium salts to coloured insoluble formazan by using the mitochondrial enzyme succinate dehydrogenase. $10 \mu \mathrm{L}$ MTT solution was added in each well and incubated at $37^{\circ} \mathrm{C}$ for $1 \mathrm{~h}$ then followed by the addition of $180 \mu \mathrm{L}$ DMSO to dissolve the formazan crystals. The absorption was then read colorimetrically at $575 \mathrm{~nm}$. The results shown are the composite of two separate experiments, and each was conducted in triplicate.

2.3. Annexin V-FITC. The effect of hydroxybenzoate lithium complexes on HT-1080 cells was measured by Annexin VFITC apoptotic assay (Bender Medsystems, Vienna, Austria). $5 \times 10^{5}$ cells were treated with an increasing concentration of $\mathrm{HBLi}$ complexes for up to $72 \mathrm{~h}$ at $37^{\circ} \mathrm{C}$ in $25 \mathrm{~cm}^{2}$ flask. Cells were trypsinized with $2 \mathrm{~mL}$ trypsin, and the cell concentration was adjusted to $10^{6}$ cells $/ \mathrm{mL}$. $0.5 \mathrm{~mL}$ of the cell suspension was seeded in Eppendorf tubes, and $10 \mu \mathrm{L}$ Media Binding Reagent was added in each tube before $1.25 \mu \mathrm{L}$
Annexin V-FITC was added. This was followed by incubation of cells at room temperature for $15 \mathrm{~min}$ before removing the medium, gentle resuspension of cells, and labelling with $10 \mu \mathrm{L}$ propidium iodide. The samples were then immediately analyzed by flow cytometry.

2.4. Scanning Electron Microscopy. HT-1080 cells were seeded into 12-well plates containing microscopic slide cover slips at a density of $15 \times 10^{3}$ cells and incubated for $48 \mathrm{~h}$ with $2 \mathrm{mM}$ or $6 \mathrm{mM}$ HBLi complexes. Cells were fixed for $1 \mathrm{~h}$ with $0.8 \%$ glutaraldehyde, $0.6 \%$ osmium tetraxide, $2 \mathrm{mM} \mathrm{CaCl}$, and $0.2 \mathrm{M}$ sucrose in $0.1 \mathrm{M}$ cacodylate buffer $\mathrm{pH}$ 7.4. HT-1080 cells were then washed several times with PBS buffer and dehydrated using a sequence of alcohol concentrations (30\%, $50 \%, 70 \%$, and $90 \%$ each for $5 \mathrm{~min}$ and $100 \%$ for $10 \mathrm{~min}$ twice). The dehydrated HT-1080 cells were then dried to the critical point in Blazers CPD 030 using $\mathrm{CO}_{2}$; cells were mounted onto $12 \mathrm{~mm}$ "Philips type" aluminium stubs using silver paint was then gold sputter coated in an Edwards S150B sputter coater. Finally, the samples were imaged using a Philips XL20 SEM.

2.5. Immunoblot Analysis. HT-1080 cells were seeded in sixwell plates at $3 \times 10^{4}$ initial density and cultured in DMEM medium. Cells were allowed to grow for $48 \mathrm{~h}$ in the presence of 0.2 or $6 \mathrm{mM}$ of $2-\mathrm{HBLi}, 3-\mathrm{HBLi}$, or $4-\mathrm{HBLi}$ under optimal culture conditions and were washed with cold PBS $(10 \mathrm{mM}$, $\mathrm{pH}$ 7.4) to remove any remaining medium. This step was followed by adding $200 \mathrm{~mL}$ of $2 \mathrm{x}$ sample buffer $(250 \mathrm{~mm}$ Tris- $\mathrm{HCl} \mathrm{pH} 6.8$, 4\% SDS, $0.006 \%$ bromophenol blue, $2 \% \beta$ mercaptoethanol; Pharmacia, Uppsala, Sweden) to each well, and the cells were then harvested using a cell scraper. HT1080 cells were treated with lysate buffer after which they were transferred to a $1.5 \mathrm{~mL}$ Eppendorf tube, heated at $100^{\circ} \mathrm{C}$ for $10 \mathrm{~min}$, cooled to room temperature, and centrifuged at $12000 \times \mathrm{g}$ for $5 \mathrm{~min}$. The supernatant was further centrifuged at $4^{\circ} \mathrm{C}$ and $16000 \times \mathrm{g}$ for $5 \mathrm{~min}$ to obtain a clear solution of protein mixture, which was used to measure the expression of $\mathrm{p} 53, \mathrm{Bcl}-2$, Bax, and caspase- 3 by Western blotting. $\beta$-Actin was used as the internal standard. Total cell lysate protein concentrations were determined according to a reported method [15].

Thirty micrograms $(22 \mu \mathrm{L})$ of protein samples and $10 \mu \mathrm{L}$ of molecular marker were loaded on to $4-12 \%$ bis-tris acrylamide gel in NuPAGE MOPS (meta-(Nmorpholino) propanesulphonic acid) SDS running buffer (Invitrogen, Life Technologies, Scotland, UK). After running the gel at $200 \mathrm{~V}$ for 30-50 $\mathrm{min}$, resolved proteins were transferred on to a nitrocellulose membrane (Sigma). Membranes were incubated first with an appropriate primary antibody (p53, Bcl-2, 


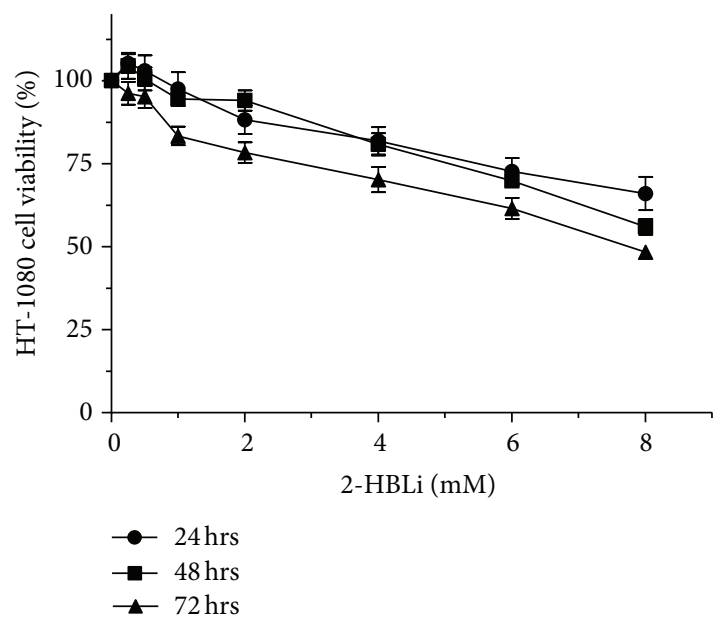

(a)

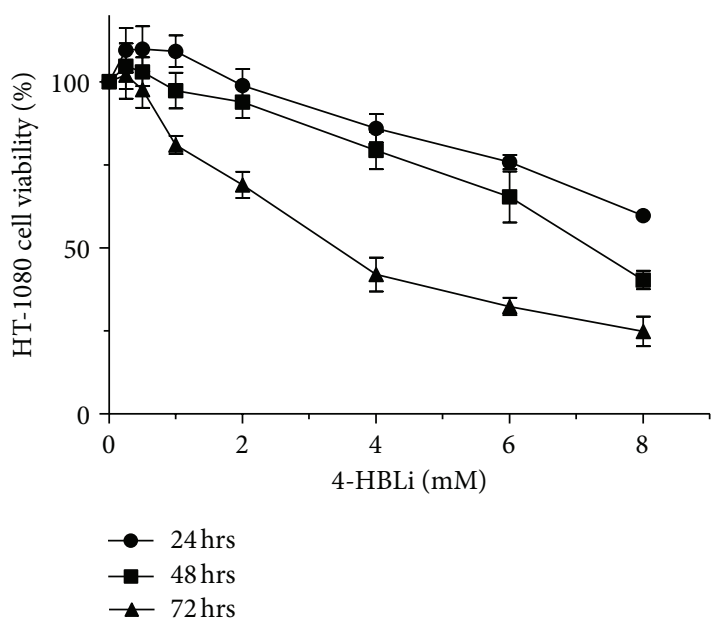

(c)

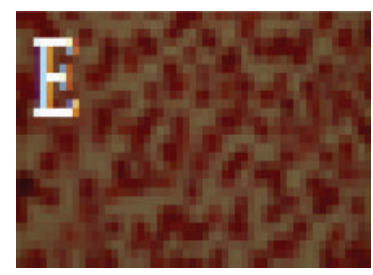

Control

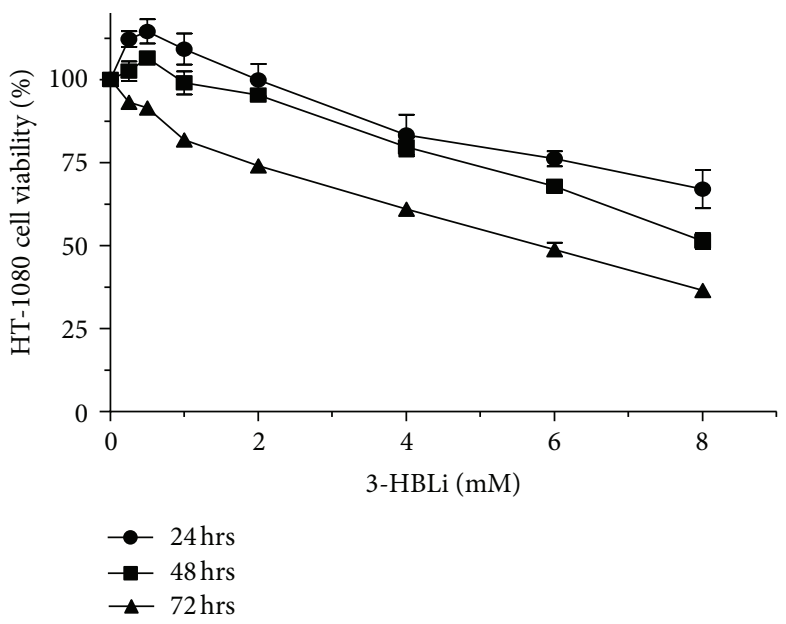

(b)

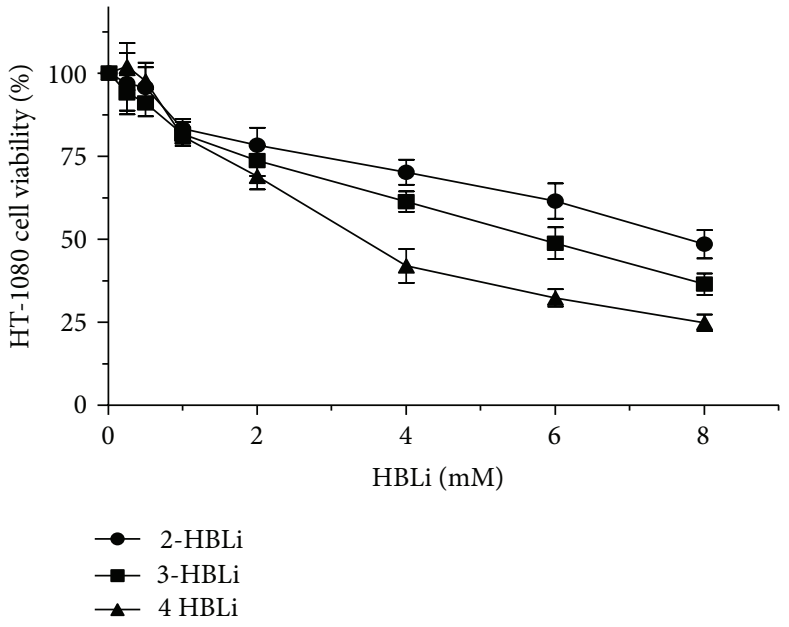

(d)

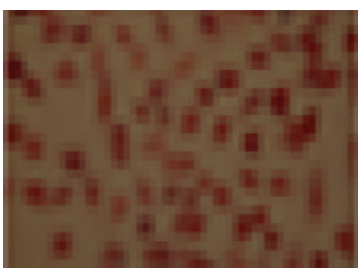

$0.2 \mathrm{mM} 4-\mathrm{HBLi}$

(e)

FIgURE 2: Time- and concentration-response curves of treated HT-1080 cells with HBLi complexes. The data was derived from MTT cell viability assay after HT-1080 cells cultured with 0-8 mM HBLi complexes for $24 \mathrm{~h}, 48 \mathrm{~h}$, and $72 \mathrm{~h}$ under optimal conditions. (a) Cell viability after treatment with $2-\mathrm{HBLi}$, (b) cell viability after treatment with $3-\mathrm{HBLi}$, (c) cell viability after treatment with $4-\mathrm{HBLi}$, (d) compassion of HT-1080 cell viability after treatment with 2-, 3-, or 4-HBLi at $72 \mathrm{~h}$, and (e) an example of the cell density for treated HT-1080 with 0,2 , and $6 \mathrm{mM}$ 4-HBLi, $72 \mathrm{~h}$.

Bax, or $\beta$-actin as a loading control and internal standard), then with peroxidase conjugated anti-mouse IgG antibody (Sigma). They were then washed and developed using a chemiluminescent reagent (Amersham, UK) and then were exposed to photographic films. The protein bands intensities were scanned and quantified using a densitometer.
2.6. Statistical Analysis. Data obtained in these experiments were evaluated using equal variance and paired Student's $t$ test. In addition, Pearson correlation coefficients were calculated, along with other statistical analyses, using Graphpad Prism 5.0 software (Graphpad Software Inc., San Diego, CA, USA). 


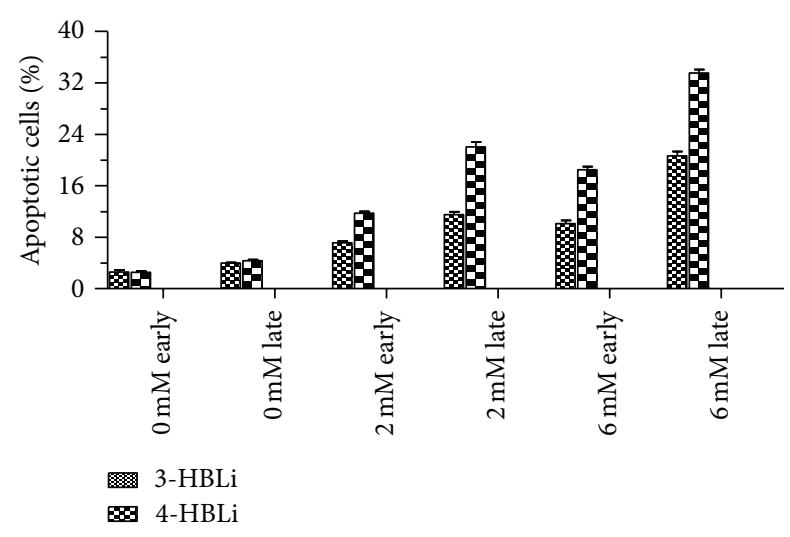

FIgURE 3: The apoptotic effect of 3-HBLi and 4-HBLi on HT-1080 cells by annexin-V/propidium iodide after treatment for $72 \mathrm{~h}$ under optimal culture conditions $(n=3)$.

\section{Results}

3.1. Cytotoxic Effects of HBLi Complexes on HT-1080 Fibrosarcoma Cells. To assess the cytotoxic effect of HBLi complexes, HT-1080 human fibrosarcoma cells were cultured with increasing concentrations of 2-, 3-, and 4-HBLi complexes for $24 \mathrm{~h}, 48 \mathrm{~h}$, and $72 \mathrm{~h}$ under optimal conditions. The results of the MTT assays showed a concentration- and time-dependent decrease in cell metabolic activity (Figures 2(a)-2(e)). The cytotoxic effect was also dependent on the $\mathrm{HBLi}$ analogue. 4-HBLi induced the highest antiproliferative activity compared to $2-\mathrm{HBLi}$ and $3-\mathrm{HBLi}$ (Figure 2). These results suggest an association between the molecular structure and cytotoxicity. 3-HBLi and 4-HBLi reduced HT-1080 cell proliferation by $7.75 \%$ and $51.16 \%$, respectively, compared to $2-\mathrm{HBLi}$ at $4 \mathrm{mM}$. At higher concentrations (i.e., $6 \mathrm{mM}$ and $8 \mathrm{mM}$ ), both 3 - and 4-HBLi complexes exerted more cytotoxic effects on HT-1080 cells (Figures 2(a)-2(d)).

\subsection{Immunochemical and Morphological Assessment of Apop-} tosis Induced by HBLi Complexes. Figure 3 shows the results that were obtained from the annexin-V/propidium iodide plots for treated HT-1080 cells with $2 \mathrm{mM}$ and $6 \mathrm{mM} 3-\mathrm{HBLi}$ or 4 -HBLi for $72 \mathrm{~h}$. Both 3 -HBLi and 4-HBLi induced apoptosis in a concentration-dependent manner. 3-HBLi induced apoptosis (early and late) by at least $18.3 \%$ at $2 \mathrm{mM}$ (Figure 3 ). The induction of apoptosis increased to $32.3 \%$ when HT1080 cells were treated with $6 \mathrm{mM} 3$-HBLi. Furthermore, 4HBLi induced apoptosis when HT-1080 cells were treated with $6 \mathrm{mM}$ (Figure 3).

In order to confirm apoptotic cell death, HT-1080 cells were also assessed morphologically by SEM after exposure to $2 \mathrm{mM}$ and $6 \mathrm{mM} 3-\mathrm{HBLi}$ or $4-\mathrm{HBLi}$ for $48 \mathrm{~h}$. Figure 4 demonstrates evidence of apoptotic effects of both complexes. Untreated HT-1080 cells showed a flat monolayer structure and retained attachment to the surface as well as pseudopodia attachment to each other. These features were not evident in cells treated with 3 -HBLi and 4-HBLi and instead were replaced by the appearance of apoptotic bodies (Figure 4).
3.3. The Effects of HBLi Complexes on the Cell Cycle Distribution of HT-1080 Cells. The effect of 3-HBLi and 4-HBLi on dividing HT-1080 cell cycle phases were analysed based on the DNA contents after culturing for $24 \mathrm{~h}$. Treatment of HT-1080 with these complexes did not induce a significant increase in the cell population at the sub-G1 phase at this time point. However, there was a significant increase in G0/G1 phase following exposure to 3-HBLi and 4-HBLi $(P=0.0204$ and $P=0.0135$, respectively; Figure 5). In the case of $4-\mathrm{HBLi}$, there was a clear concentration-dependent increase in G0/G1 $(P=0.0315)$. The arrest of HT-1080 cells in G0/G1 resulted in a suppression of cell progression to the $S$-phase. As a result of 3- or 4-HBLi treatment, DNA content at S-phase decreased in a concentration-dependent manner. At $6 \mathrm{mM}$ concentration, 4-HBLi (36.0\%) induced a significant reduction in S-phase by approximately 1.9 -fold compared to 3 -HBLi (18.9\%). These results indicate that 3 - and 4 -HBLi exert an antiproliferative activity that is to some extent dependent upon the chemical structure (Figure 5).

3.4. The Effects of HBLi Complexes Pro- and Antiapoptotic Gene Expression. In order to assess the response of treated HT-1080 cells with HBLi complexes for $48 \mathrm{~h}$, pro- and antiapoptotic proteins was analysed using Western blot analysis. The expression of $\beta$-actin was used as a loading control. Figure 6(a) shows that HBLi complexes decreased the expression of Bcl-2 in HT-1080 cells between 19 and 68\% compared to the untreated cells. The level of Bcl-2 decreased depending upon the concentration and chemical structure of the HBLi complex that was used. The trend of $\mathrm{Bcl}-2$ downregulation followed the following order: 2 -HBLi $(19 \%$ and $36 \%)<3$ $\mathrm{HBLi}(40 \%$ and $60 \%)<4-\mathrm{HBLi}(53 \%$ and $68 \%)$ at $2 \mathrm{mM}$ and $6 \mathrm{mM}$, respectively (Figure 6(a)). In contrast, the treatment of HT-1080 cells with $2 \mathrm{mM}$ or $6 \mathrm{mM}$ HBLi complexes showed a concentration-dependent increase in the expression of Bax (Figure 6(b)). Western plots analysis of Bax indicated that $2 \mathrm{mM}$ and $6 \mathrm{mM} 2-\mathrm{HBLi}$ increased their expression by $26 \%$ and $29 \%$, respectively. At the same concentrations, $3-\mathrm{HBLi}$ further increased Bax expression between $36 \%$ and $44 \%$. In addition, 4 -HBLi upregulated Bax by $45 \%$ and $51 \%$ when HT1080 cells exposed to $2 \mathrm{mM}$ and $6 \mathrm{mM}$ compared to control sample. In addition, the assignment of $\mathrm{Bcl}-2 / \mathrm{Bax}$ ratio by Western blotting (Figure 6(c)) showed that a low ratio was characteristic for the sensitivity of HT-1080 cell population to HBLi complexes. The ratios decreased in a concentrationand chemical structure-dependent manner in the following order: 4-HBLi > 3-HBLi > 2-HBLi. At $2 \mathrm{mM}$ concentration, 4-HBLi was significantly higher than $3-\mathrm{HBLi}(P=0.015)$ and 4 -HBLi $(P=0.0002)$ while at $6 \mathrm{mM} 4$-HBLi was significantly higher than $3-\mathrm{HBLi}(P=0.0053)$ and $2-\mathrm{HBLi}(P=0.0016)$.

Furthermore, the proapoptotic protein p53 (Figure 6(d)) increased in the range of $29-57 \%$ and in a concentrationdependent manner. p53 was upregulated by $29 \%$ and $31 \%$ when HT-1080 cells were treated with $2 \mathrm{mM}$ and $6 \mathrm{mM} 4-$ $\mathrm{HBLi}$, respectively. The upregulation of p53, induced by $2 \mathrm{mM}$ and $6 \mathrm{mM} 3-\mathrm{HBLi}$, was further increased by $40 \%$ and $44 \%$ when treated cells were cultured for $48 \mathrm{~h}$.

In addition, 4 -HBLi upregulated p 53 by $53 \%$ and $57 \%$ compared to control samples (Figure 6(d)). Caspase-3 was 


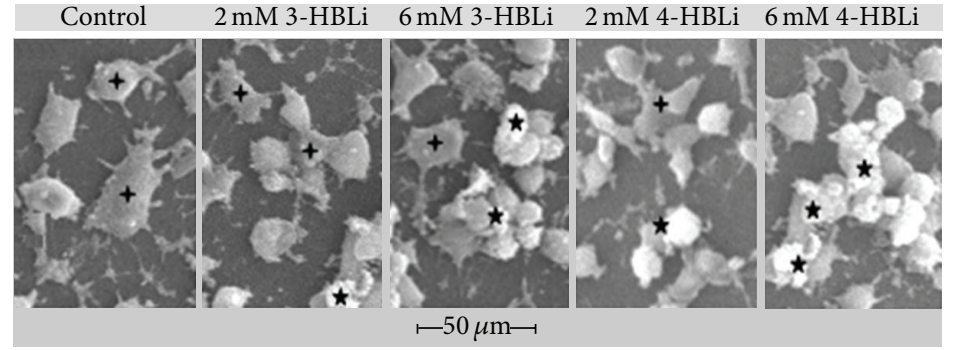

FIGURE 4: Morphological evidence of apoptosis in treated HT-1080 cells with 3-HBLi and 4-HBLi grown for $48 \mathrm{~h}$. (+) refers to normal HT-1080 cells, whereas cells retain their monolayer flat structure and pseudopodia attachments. $\left({ }^{*}\right)$ refers to apoptotic HT-1080 cells.

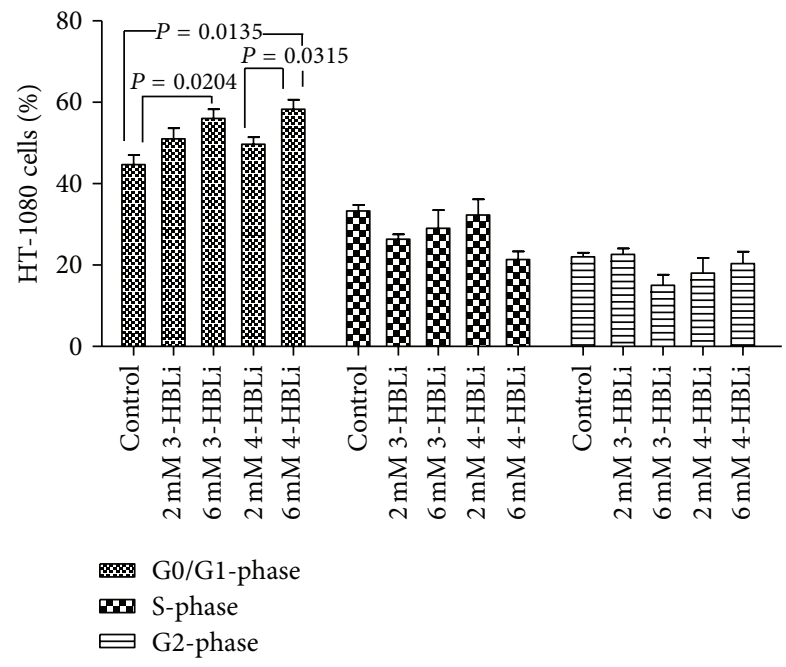

FIgUre 5: The effect of HBLi on HT-1080 cell's cycle. Cells were cultured at optimal conditions and treated separately with 2 and $6 \mathrm{mM} 3-\mathrm{HBLi}$ or $4-\mathrm{HBLi}$ for $24 \mathrm{~h}$.

also assessed immunochemically in treated HT-1080 cells. As shown in Figure 6(e), there is a concentration-dependent association between caspases-3 activation and HBLi complexes exposure. $2 \mathrm{mM}$ and $6 \mathrm{mM} 4-\mathrm{HBLi}$ induced caspases3 activation by $13 \%$ and $26 \%$, respectively. Furthermore, $3-$ HBLi upregulated caspase- 3 expression by $29 \%$ and $42 \%$ at both concentrations, respectively, compared to the control sample. In addition, exposing HT-1080 cells to $2 \mathrm{mM}$ and $6 \mathrm{mM} 4$-HBLi caused further upregulation of caspase- 3 by $35 \%$ and $43 \%$, respectively. Computing the expression of Bcl2/Bax ratios with p53 showed a negative correlation of $r=$ $-0.5758(P=0.0009)$ and $r=-0.7353(P=0.0001)$, respectively (Figure 7).

\section{Discussion}

The most common HBA is salicylic acid, chemically known as 2-HBA, the precursor of 2-acetylbenzoic acid (ABA), or aspirin. These two drugs belong to a group of compounds collectively known as nonsteroidal anti-inflammatory drugs (NSAIDs), a class of agents that were first identified in 1897 [16]. These drugs possess simple chemical structures and two functional groups that can readily interact with primary metabolites of the biological system. 2-substituted hydroxyl group at C2-position forms intramolecular $\mathrm{H}$-bonding with carboxylic group while 3- and 4-hydroxyl groups display inductive and resonance effects on carboxylic group. As a result, 2-HBA is more acidic than 3 -HBA and 4-HBA. Although, the acidity of HBLi complexes is less than HBA counterparts, the objective of this study was to determine whether 2-HBLi exerts different cytotoxicity compared to 2HBCa [14] and whether the position of the hydroxyl group at $\mathrm{C} 3$ and $\mathrm{C} 4$ makes a difference when considering the cytotoxic effects HT-1080 cells. In this respect, the reactivity of these molecules derives from their functional groups (mainly carboxylic), which is influenced by substituted hydroxyl groups at 2-, 3-, and 4-positions. Our previous research indicated that 4-HBZn selectively inhibited COX-2 and its transcription compared to ASA [6]. These complexes exhibited different cytotoxic and apoptotic effects in HT1080 cells, suggesting different environments of interaction, and hence exhibit different efficacy. HBLi complexes induced antiproliferative effects in HT-1080 cells with the order of potency as followed: 4-HBLi $>3-\mathrm{HBLi}>2$-HBLi complexes and in a concentration-dependent manner. In addition, HBLi complexes induced an arrest in G0/G1 of the cell cycle with no evidence of a G2 arrest. It may be possible that HBLi complexes exert their biological activities by direct interaction with the DNA. Research in this area indicated that organometallic complexes, particularly transition metal ion group, interact with DNA noncovalently producing changes in the structure of the DNA, thereby interfering with cell cycle and induce apoptosis [7, 17-22]. HBLi complexes induceing apoptosis, which was detected by annexin $\mathrm{V}$ labelling and confirmed morphologically by SEM, in concentration- and structure-dependent manners. Both the appearance of apoptotic bodies and the translocation of phosphatidylserine on the outer plasma membrane are common events during the induction of apoptosis that can be triggered by anticancer compounds via the extrinsic or intrinsic pathways [23-26]. The signalling of these pathway-dependent events involves the modulation of proapoptotic and antiapoptotic proteins, and their expression can be altered by anticancer drugs [25, 27]. In this respect, the molecular changes in the HBLitreated HT-1080 cells included the upregulation of Bax and downregulation of $\mathrm{Bcl}-2$ proteins to reduce $\mathrm{Bcl}-2 / \mathrm{Bax}$ ratios. Bax enhances apoptosis via the intrinsic pathway, which involves cytochrome $c$ that regulates the expression of caspases- 9 and then caspase- 3 [23, 28, 29]. Other 


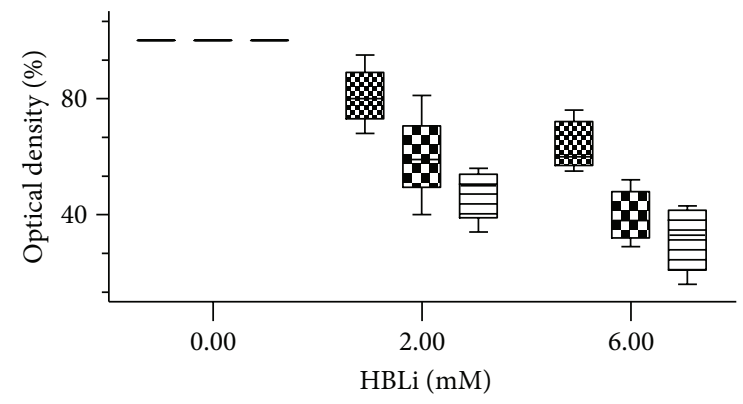

(a)

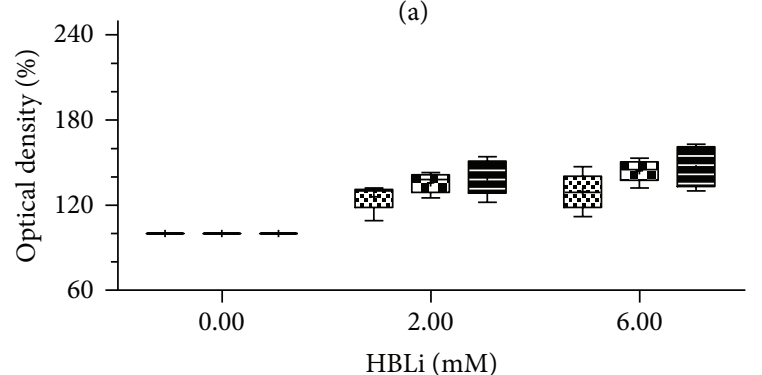

(b)

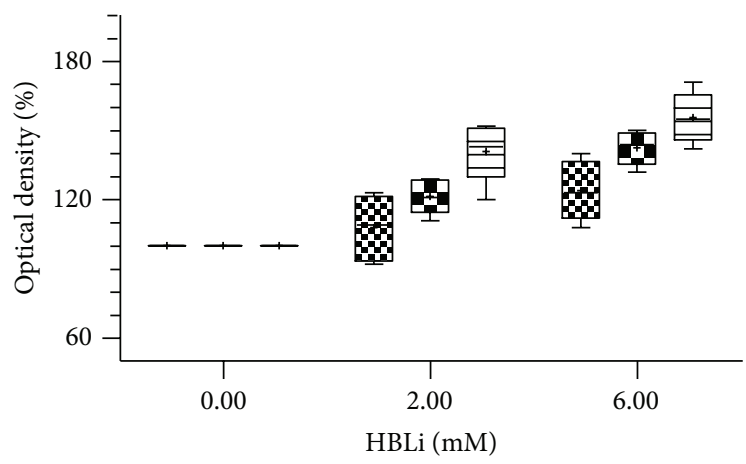

$802-\mathrm{HBLi}$

I-HBLi

4-HBLi
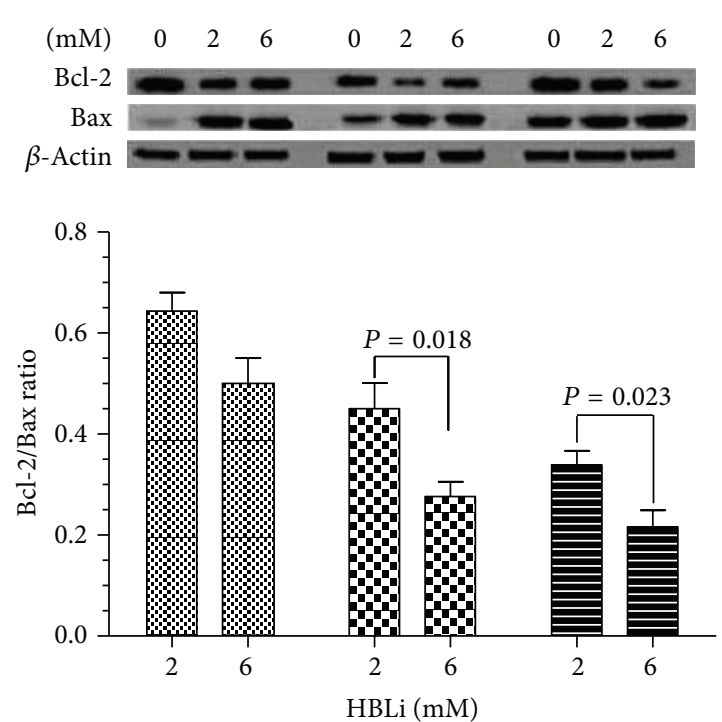

(c)

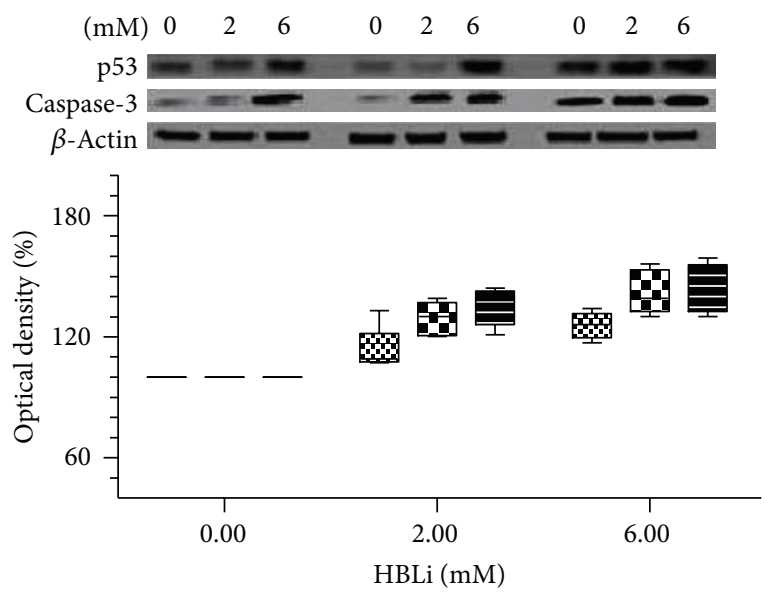

38. $2-\mathrm{HBLi}$

표 3-HBLi

ב $4-\mathrm{HBLi}$

(d)

(e)

Figure 6: Immunoblotting analysis of (a) Bcl-2, (b) Bax, (c) ratios of $\mathrm{Bax} / \mathrm{Bcl}-2$, (d) p53, and (e) caspase-3 protein expressions in treated HT-1080 cells cultured with different concentrations of 2 -HBLi, 3-HBLi, and 4-HBLi for $48 \mathrm{~h}$. $\beta$-Actin antibody was used as an internal standard. Immunoblotting of each protein was conducted on three independent lysates. The values for optical density (OD) were calculated by normalizing relative optical density values to that of the control. Thereby OD for control is $100 \%$ while treatment is either below or above $100 \%$. Normalized values were calculated as ratios of $\left(\mathrm{OD}_{\text {control }}-\mathrm{OD}_{\text {treatment }} / \mathrm{OD}_{\text {control }}\right)$.

organometallic complexes, such as $\mathrm{HB} \mathrm{Na}^{+}, \mathrm{Ca}^{2+}$, and $\mathrm{Zn}^{2+}$ also modulated $\mathrm{Bcl}-2$ and Bax protein expression [7, 30, 31]. In addition, HBLi complexes also induced p53 and caspase- 3 in a concentration-dependent manner. The induction of p53 plays a vital role in regulating apoptosis and the cell cycle $[32,33]$. Therefore, a loss of p53 enhances survival of cells with DNA damage and helps cancer progression [32-34]. The upregulation of p53 and caspase- 3 in HBLi-treated HT-1080 cells is likely to agree with the decreasing $\mathrm{Bcl}-2 / \mathrm{Bax}$ ratios, as indicated from the negative correlation.

\section{Conclusion}

These results demonstrate that HBLi complexes exert apoptotic effects in a concentration- and chemical structuredependent manner. The cellular modulation of HT-1080 cells by HBLi complexes shows an association between apoptosis induction and reduction in $\mathrm{Bcl}-2 / \mathrm{Bax}$ ratios, suggesting that it is a potential molecular marker for predicting response to HBLi complexes. Furthermore, although HBLi complexes exert cytotoxic effects in HT-1080 cells at relatively high 


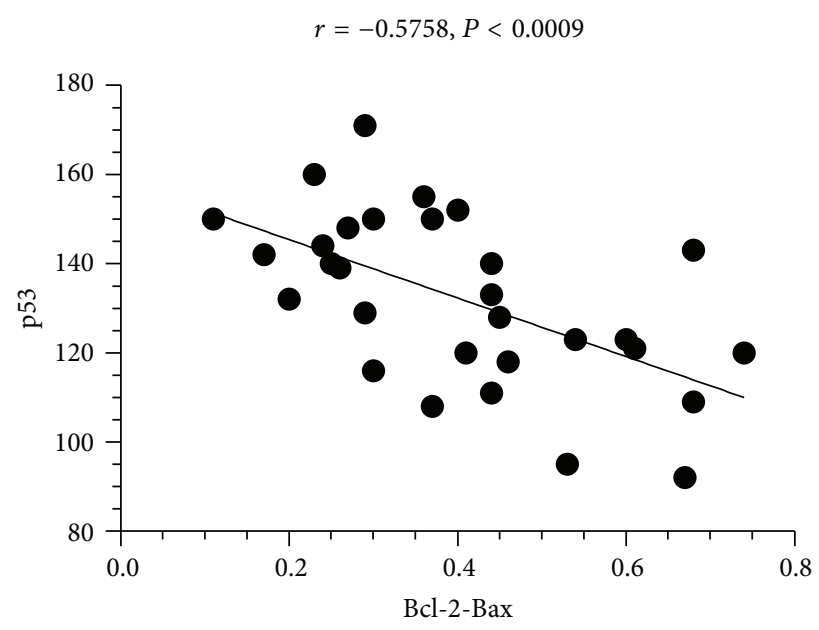

(a)

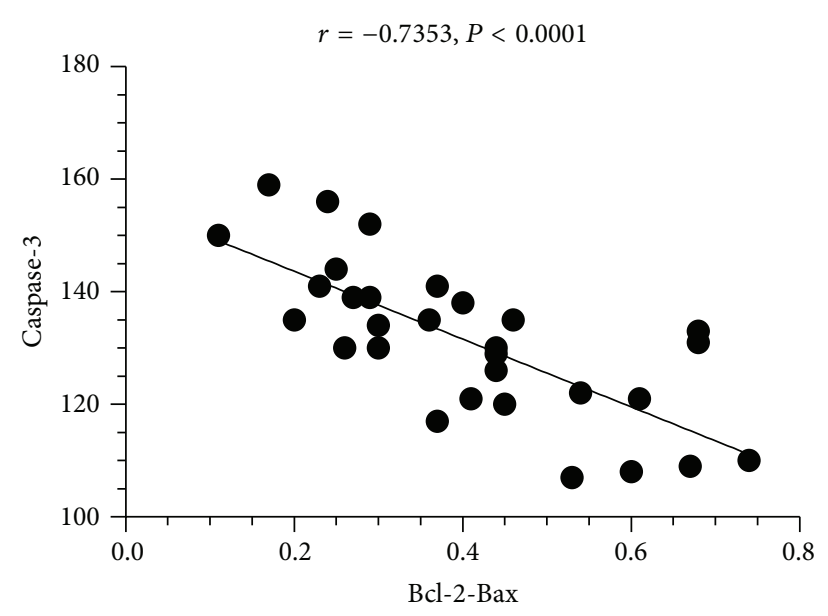

(b)

Figure 7: Pearson correlation coefficient pattern between Bcl-2/Bax ratios, p53, and caspases-3, respectively.

concentrations, they are more potent mole for mole than aspirin so the results here provide some important impetus for future research. Indeed, here we provide the first evidence that HBLi complexes may have therapeutic potential as anticancer agents.

\section{Conflict of Interests}

Authors declare that there is no any conflict of interests.

\section{References}

[1] A. H. Cory and J. G. Cory, "Phenolic compounds, sodium salicylate and related compounds, as inhibitors of tumor cell growth and inducers of apoptosis in mouse leukemia L1210 cells," In Vivo, vol. 19, no. 1, pp. 31-36, 2005.

[2] N. M. Vad, I. H. Shaik, R. Mehvar, and M. Y. Moridani, "Metabolic bioactivation and toxicity of ethyl 4-hydroxybenzoate in human SK-MEL-28 melanoma cells," Journal of Pharmaceutical Sciences, vol. 97, no. 5, pp. 1934-1945, 2008.

[3] M. Cichocki, J. Blumczyńska, and W. Baer-Dubowska, "Naturally occurring phenolic acids inhibit 12-O-tetradecanoylphorbol-13-acetate induced NF- $\kappa \mathrm{B}$, iNOS and COX-2 activation in mouse epidermis," Toxicology, vol. 268, no. 1-2, pp. 118124,2010 .

[4] J.-D. Zhang, Q.-Z. Zhu, S.-J. Li, and F.-M. Tao, "Prediction of aqueous $\mathrm{pKa}$ values of hydroxybenzoic acid using hydrogenbonded complexes with ammonia," Chemical Physics Letters, vol. 475, no. 1-3, pp. 15-18, 2009.

[5] A. K. Singla and H. Wadhwa, "Zinc-aspirin complex: synthesis, physicochemical and biological evaluation," International Journal of Pharmaceutics, vol. 108, no. 3, pp. 173-185, 1994.

[6] J. G. Mahdi, N. M. Al-Musayeib, E. J. Mahdi et al., "Pharmacological importance of hydroxybenzoates in modulating 11 cell inflammation, proliferation and apoptosis with a special reference to $\beta$-D-salicin and salicylic acid," European Journal of Inflammation, vol. 11, no. 2, pp. 315-326, 2013.
[7] C. Pepper, J. G. Mahdi, A. G. S. Buggins et al., "Two novel aspirin analogues show selective cytotoxicity in primary chronic lymphocytic leukaemia cells that is associated with dual inhibition of Rel A and COX-2," Cell Proliferation, vol. 44, no. 4, pp. 380390, 2011.

[8] J. G. Mahdi, C. J. Pepper, M. A. Alkarrawi, A. J. Mahdi, and I. D. Bowen, "Sub-millimolar concentration of the novel phenolbased compound, 2-hydroxy benzoate zinc, induces apoptosis in human HT-1080 fibrosarcoma cells," Cell Proliferation, vol. 43, no. 1, pp. 95-102, 2010.

[9] A. K. Jain and S. Bhattacharya, "Recent developments in the chemistry and biology of G-Quadruplexes with reference to the DNA groove binders," Current Pharmaceutical Design, vol. 18, no. 14, pp. 1917-1933, 2012.

[10] A. Paul and S. Bhattacharya, "Chemistry and biology of DNAbinding small molecules," Current Science, vol. 102, pp. 212-231, 2012.

[11] I. Kostova, "Platinum complexes as anticancer agents," Recent Patents on Anti-Cancer Drug Discovery, vol. 1, no. 1, pp. 1-22, 2006.

[12] S. Rafique, M. Idrees, A. Nasim et al., "Transition metal complexes as potential therapeutic agents," Biotechnology and Molecular Biology Reviews, vol. 5, pp. 38-45, 2010.

[13] P. Schwenger, E. Y. Skolnik, and J. Vilček, "Inhibition of tumor necrosis factor-induced p42/p44 mitogen-activated protein kinase activation by sodium salicylate," Journal of Biological Chemistry, vol. 271, no. 14, pp. 8089-8094, 1996.

[14] L. Klampfer, J. Cammenga, H.-G. Wisniewski, and S. D. Nimer, "Sodium salicylate activates caspases and induces apoptosis of myeloid leukemia cell lines," Blood, vol. 93, no. 7, pp. 2386-2394, 1999.

[15] J.-O. Karlsson, K. Ostwald, C. Kabjorn, and M. Andersson, "A method for protein assay in Laemmli buffer," Analytical Biochemistry, vol. 219, no. 1, pp. 144-146, 1994.

[16] J. G. Mahdi, A. J. Mahdi, A. J. Mahdi, and I. D. Bowen, "The historical analysis of aspirin discovery, its relation to the willow tree and antiproliferative and anticancer potential," Cell Proliferation, vol. 39, no. 2, pp. 147-155, 2006.

[17] N. Hadjiliadis and E. Sletten, Eds., Metal Complex-DNA Interactions, Blackwell Publishing, 2009. 
[18] S. Neidle, "DNA minor-groove recognition by small molecules," Natural Product Reports, vol. 18, no. 3, pp. 291-309, 2001.

[19] S. D. Schimler, D. J. Hall, and S. L. Debbert, "Anticancer, (hexacarbonyldicobalt)propargyl aryl ethers: synthesis, antiproliferative activity, apoptosis induction, and effect on cellular oxidative stress," Journal of Inorganic Biochemistry, vol. 119, pp. 28-37, 2013.

[20] H. J. Yu, Y. Chen, L. Yu et al., "Synthesis, visible light photocleavage, antiproliferative and cellular uptake properties of ruthenium complex $[\mathrm{Ru}(\text { phen }) 2 \text { (mitatp) }]^{2+,}$, European Journal of Medicinal Chemistry, vol. 55, pp. 146-154, 2012.

[21] S. T. Von, H. L. Seng, H. B. Lee et al., "DNA molecular recognition and cellular selectivity of anticancer metal(II) complexes of ethylenediaminediacetate and phenanthroline: multiple targets," Journal of Biological Inorganic Chemistry, vol. 17, pp. 57-69, 2012.

[22] L. Bica, J. Meyerowitz, S. J. Parker et al., "Cell cycle arrest in cultured neuroblastoma cells exposed to a bis(thiosemicarbazonato) metal complex," BioMetals, vol. 24, no. 1, pp. 117-133, 2011.

[23] S. Fulda and K.-M. Debatin, "Extrinsic versus intrinsic apoptosis pathways in anticancer chemotherapy," Oncogene, vol. 25, no. 34, pp. 4798-4811, 2006.

[24] J. R. García-Berrocal, J. Nevado, R. Ramírez-Camacho et al., "The anticancer drug cisplatin induces an intrinsic apoptotic pathway inside the inner ear," British Journal of Pharmacology, vol. 152, no. 7, pp. 1012-1020, 2007.

[25] D. R. Green and J. C. Reed, "Mitochondria and apoptosis," Science, vol. 281, no. 5381, pp. 1309-1312, 1998.

[26] S. J. Riedl and G. S. Salvesen, "The apoptosome: signalling platform of cell death," Nature Reviews Molecular Cell Biology, vol. 8, no. 5, pp. 405-413, 2007.

[27] K.-M. Debatin, "Apoptosis pathways in cancer and cancer therapy," Cancer Immunology, Immunotherapy, vol. 53, no. 3, pp. 153-159, 2004.

[28] S. Fulda and K.-M. Debatin, "Targeting apoptosis pathways in cancer therapy," Current Cancer Drug Targets, vol. 4, no. 7, pp. 569-576, 2004.

[29] M. O. Hengartner, "The biochemistry of apoptosis," Nature, vol. 407, no. 6805, pp. 770-776, 2000.

[30] J. G. Mahdi, M. A. Alkarrawi, A. J. Mahdi, I. D. Bowen, and D. Humam, "Calcium salicylate-mediated apoptosis in human HT-1080 fibrosarcoma cells," Cell Proliferation, vol. 39, no. 4, pp. 249-260, 2006.

[31] E. J. Lee, H. G. Park, and H. S. Kang, "Sodium salicylate induces apoptosis in HCT116 colorectal cancer cells through activation of p38MAPK," International Journal of Oncology, vol. 23, no. 2, pp. 503-508, 2003.

[32] P. H. Shaw, "The role of p53 in cell cycle regulation," Pathology Research and Practice, vol. 192, no. 7, pp. 669-675, 1996.

[33] J. L. A. Abrahamson, J. M. Lee, and A. Bernstein, "Regulation of p53-mediated apoptosis and cell cycle arrest by steel factor," Molecular and Cellular Biology, vol. 15, no. 12, pp. 6953-6960, 1995.

[34] Z. Wang and Y. Sun, "Targeting p53 for novel anticancer therapy," Translational Oncology, vol. 3, no. 1, pp. 1-12, 2010. 


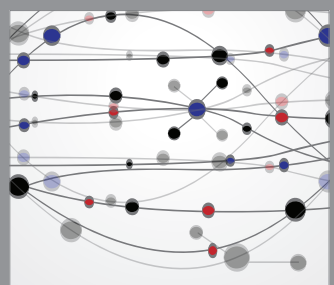

The Scientific World Journal
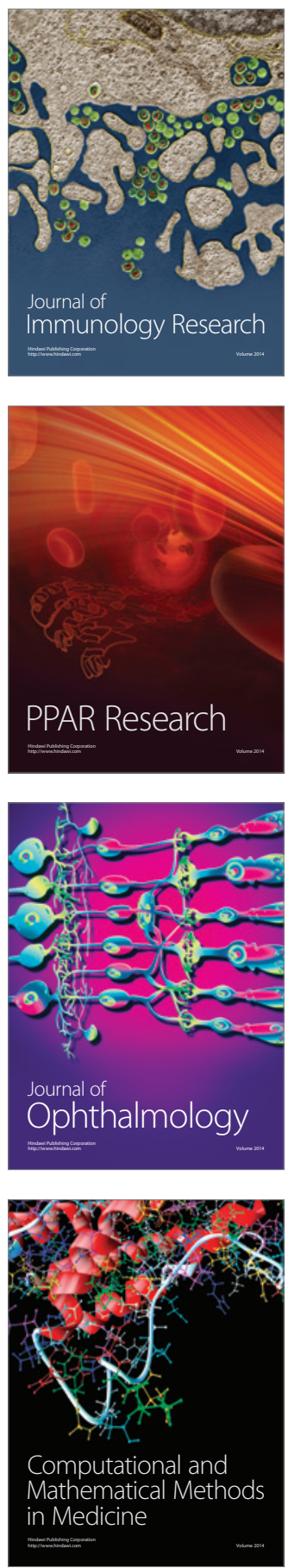

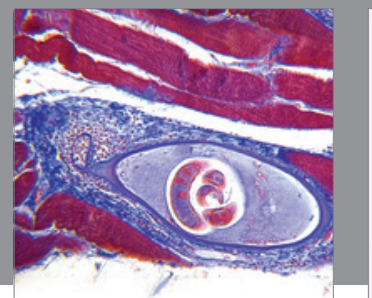

Gastroenterology

Research and Practice
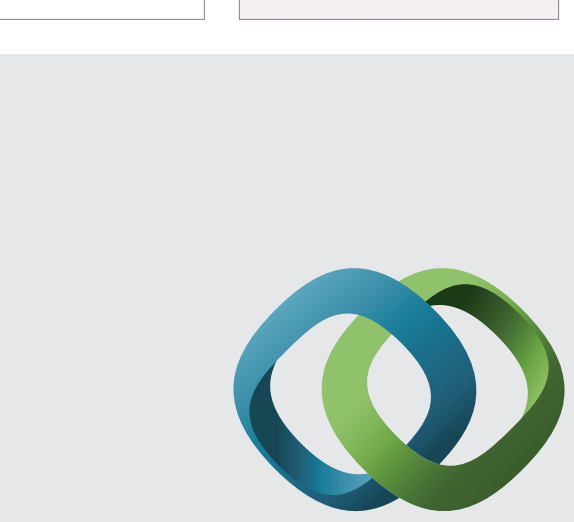

\section{Hindawi}

Submit your manuscripts at

http://www.hindawi.com
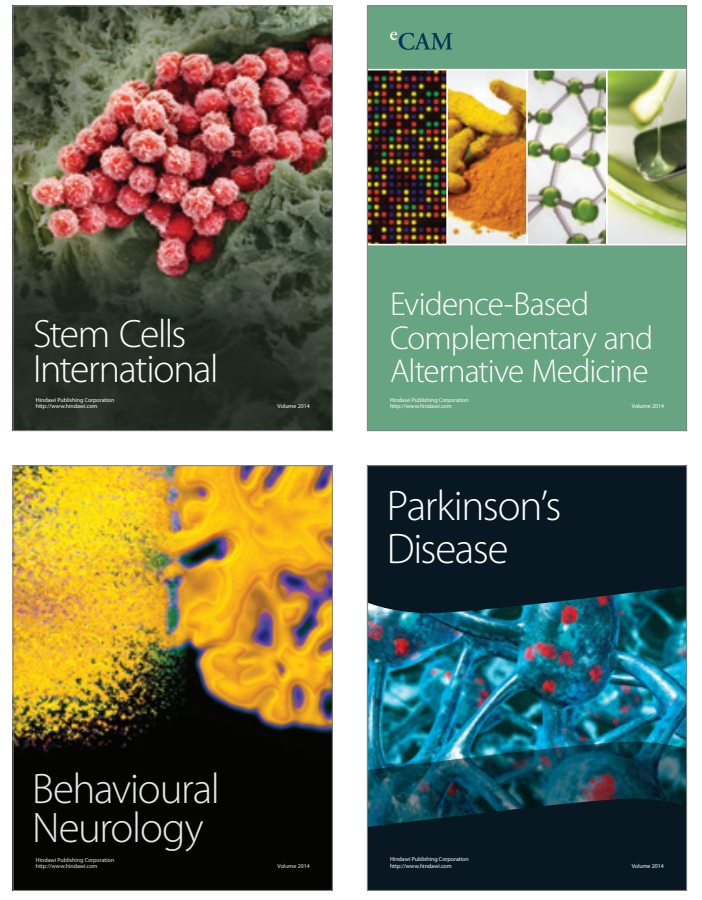
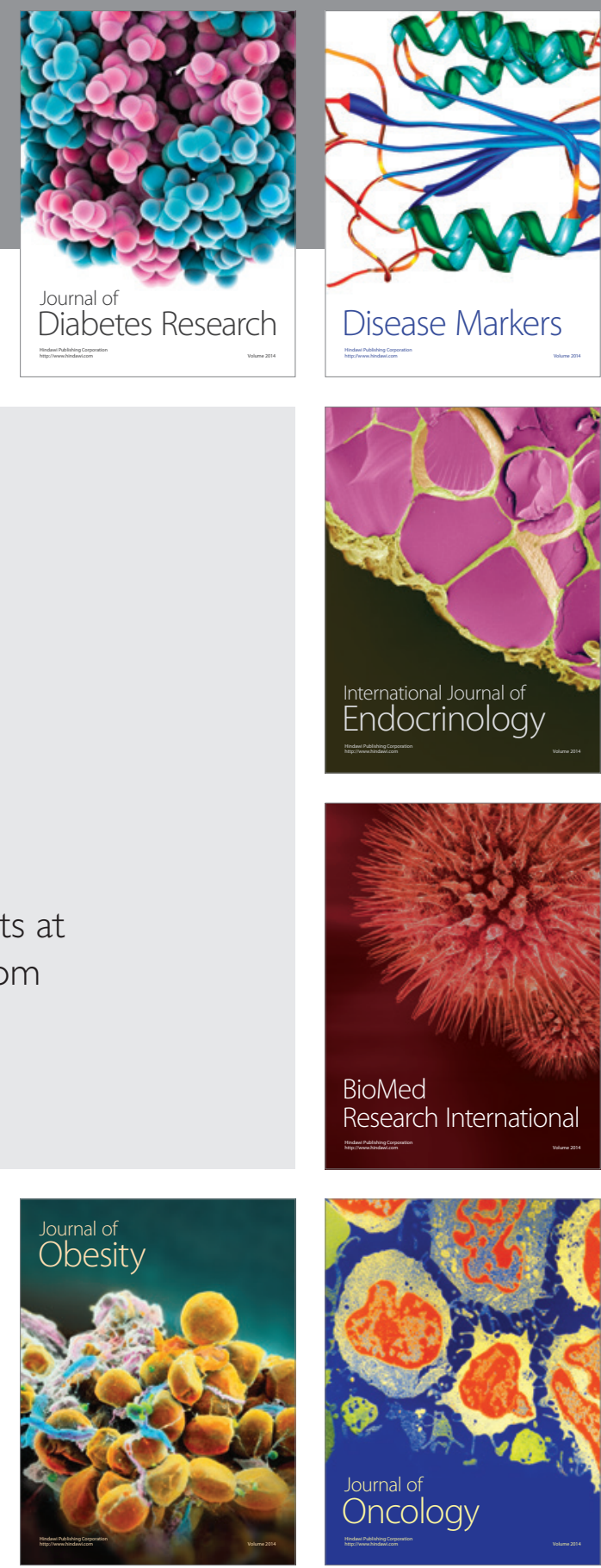

Disease Markers
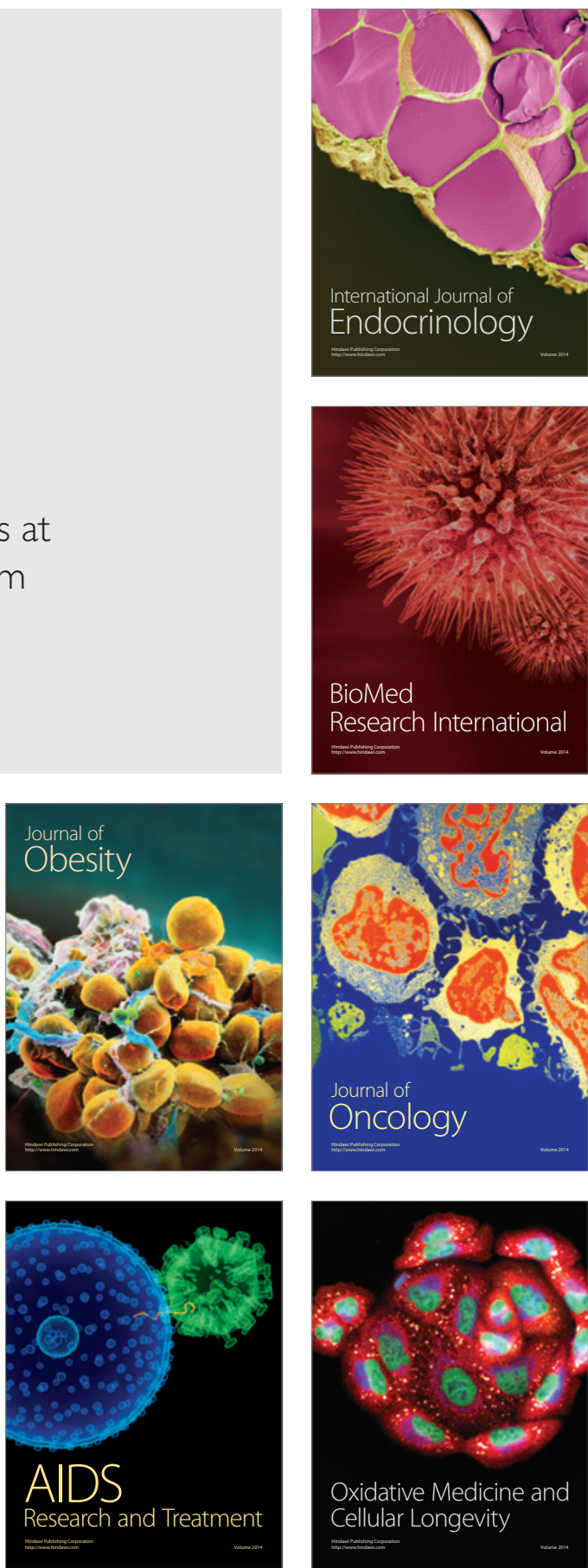